\title{
Terminally Differentiated Epithelial Cells of the Thymic Medulla and Skin Express Nicotinic Acetylcholine Receptor Subunit $\alpha 3$
}

\author{
Aichurek Soultanova, Alexandra R. Panneck, Amir Rafiq, and Wolfgang Kummer \\ Institute of Anatomy and Cell Biology, German Center for Lung Research, Justus-Liebig-University Giessen, Aulweg 123, \\ 35385 Giessen, Germany \\ Correspondence should be addressed to Wolfgang Kummer; wolfgang.kummer@anatomie.med.uni-giessen.de
}

Received 22 April 2014; Accepted 13 June 2014; Published 3 July 2014

Academic Editor: Koichiro Kawashima

Copyright (C) 2014 Aichurek Soultanova et al. This is an open access article distributed under the Creative Commons Attribution License, which permits unrestricted use, distribution, and reproduction in any medium, provided the original work is properly cited.

\begin{abstract}
In the thymus, $\mathrm{T}$ cell maturation is influenced by cholinergic signaling, and the predominantly expressed receptor is the $\alpha 3$ subunit of nicotinic acetylcholine receptors, encoded by the chrna3 gene. We here determined its cellular distribution utilizing an appropriate eGFP-expressing reporter mouse strain. Neither T cells (CD4, CD8) nor mesenchymal cells (desmin-positive) expressed eGFP. In the thymic medulla, eGFP-positive cells either were scattered or, more frequently, formed small clusters resembling Hassall's corpuscles. Immunolabeling revealed that these cells were indeed terminally differentiated epithelial cells expressing keratin 10 (K10) but neither typical cortical (K8, K18) nor medullary keratins (K5, K14). These labeling patterns reflected those in the epidermis of the skin, where overlap of K10 and eGFP expression was seen in the stratum granulosum, whereas underlying basal cells displayed K5-immunoreactivity. A substantial portion of thymic eGFP-positive cells was also immunoreactive to chromogranin A, a peptide previously reported in epidermal keratinocytes in the stratum granulosum. Its fragment catestatin has multiple biological activities, including suppression of proinflammatory cytokine release from macrophages and inhibition of $\alpha 3 \beta 4 \mathrm{nAChR}$. The present findings suggest that its thymic production and/or release are under cholinergic control involving nAChR containing the $\alpha 3$-subunit.
\end{abstract}

\section{Introduction}

The thymus is the site of step-wise maturation of naïve $\mathrm{T}$ cells from immature thymocytes which occurs along with positive and negative selection processes while thymocytes migrate from the cortex to the medulla. These processes are influenced by cholinergic signaling [1-4], and acetylcholine ( $\mathrm{ACh}$ ) is endogenously synthesized in the thymus [5-7].

Signaling via nicotinic ACh receptors (nAChR) has received particular attention. These receptors are pentamers composed of various subunit combinations. The "muscle type" nAChR originally identified at the motor endplate consists of two $\alpha 1$-, one $\beta 1$-, one $\varepsilon^{-}$(or $\gamma$ - at fetal stage), and one $\delta$-subunit, and these are also expressed by myoid $[8,9]$ and epithelial cells of the thymic medulla [10-13]. Thymic expression and presentation of muscle-type nAChR subunits have been associated with a frequent $(85 \%)$ variant of myasthenia gravis, a disease of the motor endplate, where autoantibodies against such subunits are formed, as the thymus frequently shows abnormal structure in this condition and thymectomy is beneficial for the patients [14].

"Neuronal" nAChR are homo- or heteromers of $\alpha$ subunits $2-7$ and 9-10 ( $\alpha 8$ is expressed only in chicken) and $\beta$-subunits 2-4 [15-17]. Despite their designation as "neuronal" they are widely expressed outside the nervous system including the thymus $[18,19]$. Amongst them, subunits $\alpha 3$, $\alpha 5$, and $\beta 4$ exhibit highest expression in early postnatal mouse thymus, reaching $7-15 \%$ of mRNA content found in brain as standard [19]. Their genes-chrna3, chrna5, and chrnb4-are clustered on chromosome 9 in mice, and, when coexpressed, the translated proteins assemble to functional $\alpha 3(\alpha 5) \beta 4$ nAChR with either $2 \alpha$ - and $3 \beta$-subunit or $3 \alpha$ and $2 \beta$-subunit chains $[15,20]$. The $\alpha 3$-subunit is essential for receptor function and may occur with or without an additional $\alpha 5$-subunit in these receptors while the $\alpha 5$-subunit 
does not form functional receptors without additional $\alpha$ subunits [15]. Messenger RNAs coding for these subunits have been detected in isolated thymocytes and cultured thymic epithelial cells (TEC) obtained from children undergoing corrective cardiac surgery [18], but it is still unclear which specific thymic cell types express these receptors in situ.

In view of the reported specificity problems associated with immunohistochemical detection of $\mathrm{nAChR}$ subunits [21], we utilized a reporter mouse strain expressing eGFP under the control of the chrna3 promoter coding for the essential $\alpha 3$-subunit [22]. To further characterize and identify eGFP-positive cells in the thymus, tissue sections were subjected to immunohistochemistry with marker antibodies for subsets of thymocytes (CD4, CD8), myoid and mesenchymal (desmin) and thymic epithelial cells. Thymic epithelial cells are heterogeneous and can be classified according to various criteria. A broad classification divides them into four general types (with further subpopulations [23, 24]): (a) subcapsular/paraseptal/perivascular, (b) cortical, (c) medullary (mTEC), and (d) terminally differentiated mTEC, usually arranged in Hassall's corpuscles [25-28]. These types differ in their intermediate filament content, with cortical and a small population of mTEC expressing keratins typical for simple epithelia $(\mathrm{K} 8, \mathrm{~K} 18)[23,28,29]$, the majority of mTEC keratins characteristic for immature basal cells of stratified epithelia, that is, $\mathrm{K} 5$ and $\mathrm{K} 14$ [24, 28, 30], and terminally differentiated cells of Hassall's corpuscles (in human) and Hassall's corpuscles-like structures (in mice) expressing K10 [31].

\section{Materials and Methods}

2.1. Animals and Tissue Collection. Transgenic mice expressing eGFP under chrna3 promoter [22] were killed with an overdose of isoflurane (Abbott, Wiesbaden, Germany). Animals of either gender $(N=9)$ were transcardially perfused with heparin-containing rinsing solution [32] followed by either $4 \%$ paraformaldehyde in $0.1 \mathrm{M}$ phosphate buffer ( $\mathrm{pH}=7.4$ ) or Zamboni fixative (2\% paraformaldehyde, $15 \%$ saturated picric acid in $0.1 \mathrm{M}$ phosphate buffer, $\mathrm{pH} 7.4$ ). Thymi and hairy skin of the head were dissected and fixed overnight by immersion in the same fixative used for perfusion. In 5 additional animals, tissues were immersion-fixed overnight in Zamboni fixative without prior perfusion. Specimens were washed in $0.1 \mathrm{M}$ phosphate buffer, $\mathrm{pH}=7.4$, for $30 \mathrm{~h}$, incubated overnight in $18 \%$ sucrose in $0.1 \mathrm{M}$ phosphate buffer, and frozen in OCT compound (Sakura Finetek, Staufen, Germany) using liquid nitrogen.

2.2. Immunohistochemistry. Thymi and hairy skin of the head were cut with a cryostat into $4-10 \mu \mathrm{m}$ thick sections and airdried for $1 \mathrm{~h}$. Nonspecific protein binding sites were saturated with $10 \%$ horse serum, $0.5 \%$ Tween, and $0.1 \%$ BSA in PBS $(0.005 \mathrm{M}$ phosphate buffer, $\mathrm{pH}=7.4$, with $0.45 \% \mathrm{NaCl})$. Sections were incubated for $16 \mathrm{~h}$ with primary antibodies diluted in PBS with doubled salt concentration and containing $0.01 \% \mathrm{NaN}_{3}$. Each antibody was applied to thymi from at least 6 animals. Antibody dilutions and sources are specified in Table 1. After washing in PBS, sections were covered with Cy3-conjugated donkey anti-rabbit IgG (1:2000; Chemicon, Darmstadt, Germany) or donkey anti-rat IgG (1:1000; Dianova, Hamburg, Germany) for $1 \mathrm{~h}$, washed, postfixed in $4 \%$ paraformaldehyde in $0.1 \mathrm{M}$ phosphate buffer, washed again, and mounted in carbonate-buffered glycerol $(1: 1, \mathrm{pH}=$ 8.6). Controls were run by replacing primary antibodies with unrelated isotypes from the same species and by omission of first antibodies. Sections were evaluated with an Axioplan 2 epifluorescence microscope equipped with an AxioCam MRm camera system (Zeiss, Jena, Germany). Except overall adjustment of brightness, no further manipulations of digital images were performed.

\section{Results}

The major nicotinic receptor mediating synaptic transmission in autonomic ganglia is a heteropentamer of $\alpha 3(\alpha 5) \beta 4$ subunits $[15,33]$. Accordingly, autonomic nerve fibers surrounding thymic arteries exhibited intense eGFP fluorescence (Figure 1(a)). Besides these nerve fibers, positive cells were observed in the thymic medulla with some preference to the corticomedullary junction, but practically sparing the external cortex (Figures 1(b) and 1(c)). Such cells typically formed clusters. The larger clusters showed characteristic morphology of murine Hassall's corpuscle-like structures. Infrequently observed singular eGFP-positive cells and those forming groups of two or three, displayed variable shape, ranging from round to oval to elongated with processes emerging from the cell body (Figures 1(d)-1(i)). According to this complex shape, these eGFP-positive cells were not thymocytes and did not express CD4 or CD8 (Figure 2).

Desmin is a marker for thymic myoid cells and mesenchymal cells [9]. Accordingly, immunolabeling revealed a network of fine processes in the thymic medulla and a few positive cells bodies. Colocalization with eGFP fluorescence was not observed (Figure 3).

K8- and K18-immunoreactive epithelial cell processes formed a dense network in the cortex, and a small population of less branched mTEC was also K8- and K18immunoreactive, as previously described [34]. Neither of these antibodies, however, labeled eGFP-positive cells (Figures 4(a) and 4(b)). In the medulla, a dense mesh of K5and K14-immunoreactive cell processes was noted. Such processes surrounded eGFP-positive cells which were larger than keratin-immunoreactive cell bodies and were K5/K14negative (Figures 4(c) and 4(d)). This spatial arrangement resembled that of the epidermis where $\mathrm{K} 5$ is expressed by the basal cells and its expression ceases when keratinocytes terminally differentiate in the stratum granulosum $[35,36]$. Accordingly, we observed eGFP fluorescence in the K5negative stratum granulosum of hairy skin and K5-positive cells in the underlying stratum basale and the lowermost stratum spinosum (Figure 5(a)). In the epidermis, keratinocytes switch to K10 expression in the stratum spinosum which is kept in the stratum granulosum. This partly overlaps with 
Table 1: Primary antibodies used in the study.

\begin{tabular}{|c|c|c|c|c|c|c|}
\hline Target & Immunogen & Host & Clone & Dilution & Catalog number & Company \\
\hline $\mathrm{CD} 4$ & Not specified & Rat & $\begin{array}{l}\text { Monoclonal, } \\
\text { clone RM4-5 }\end{array}$ & $1: 400$ & IH93-0042-91 & $\begin{array}{c}\text { eBioscience, } \\
\text { Frankfurt am Main, } \\
\text { Germany }\end{array}$ \\
\hline $\mathrm{CD} 8$ & Not specified & Rat & $\begin{array}{l}\text { Monoclonal, } \\
\text { clone 53-6.7 }\end{array}$ & $1: 400$ & IH93-0081-91 & $\begin{array}{c}\text { eBioscience, } \\
\text { Frankfurt am Main, } \\
\text { Germany }\end{array}$ \\
\hline Chromogranin A & $\begin{array}{l}\text { Synthetic peptide } \\
\text { corresponding to residues } \\
\text { near the C-terminus of human } \\
\text { chromogranin A }\end{array}$ & Rabbit & Polyclonal & $1: 25$ & $1782-1$ & $\begin{array}{l}\text { Epitomics, } \\
\text { Cambridge, UK }\end{array}$ \\
\hline Desmin & $\begin{array}{l}\text { Synthetic peptide } \\
\text { corresponding to C-terminus } \\
\text { of human desmin }\end{array}$ & Rabbit & $\begin{array}{l}\text { Monoclonal, } \\
\text { clone Y66 }\end{array}$ & $1: 200-1: 800$ & $04-585$ & $\begin{array}{l}\text { Merck Millipore, } \\
\text { Darmstadt, Germany }\end{array}$ \\
\hline Keratin 5 & $\begin{array}{l}\text { Synthetic peptide } \\
\text { corresponding to C-terminus } \\
\text { of human keratin } 5\end{array}$ & Rabbit & $\begin{array}{l}\text { Monoclonal, } \\
\text { clone SP27 }\end{array}$ & $1: 50-1: 200$ & SPB-M3270 & $\begin{array}{l}\text { Spring, Pleasanton, } \\
\text { CA, USA }\end{array}$ \\
\hline Keratin 8 & $\begin{array}{l}\text { Synthetic peptide } \\
\text { corresponding to C-terminus } \\
\text { of human keratin } 8\end{array}$ & Rabbit & $\begin{array}{l}\text { Monoclonal, } \\
\text { clone SP102 }\end{array}$ & $1: 50$ & SPB-M4020 & $\begin{array}{l}\text { Spring, Pleasanton, } \\
\text { CA, USA }\end{array}$ \\
\hline Keratin 10 & $\begin{array}{l}\text { C-terminus of the mouse } \\
\text { keratin } 10\end{array}$ & Rabbit & Polyclonal & $1: 400$ & PRB-159P & $\begin{array}{c}\text { Covance, Münster, } \\
\text { Germany }\end{array}$ \\
\hline Keratin 14 & $\begin{array}{l}\text { Synthetic peptide } \\
\text { corresponding to C-terminus } \\
\text { of human keratin } 14\end{array}$ & Rabbit & $\begin{array}{l}\text { Monoclonal, } \\
\text { clone SP53 }\end{array}$ & $1: 400$ & SPB-M3534 & $\begin{array}{l}\text { Spring, Pleasanton, } \\
\text { CA, USA }\end{array}$ \\
\hline Keratin 18 & $\begin{array}{l}\text { Synthetic peptide } \\
\text { corresponding to C-terminus } \\
\text { of human keratin } 18\end{array}$ & Rabbit & $\begin{array}{l}\text { Monoclonal, } \\
\text { clone SP69 }\end{array}$ & $1: 200$ & SPB-M3694 & $\begin{array}{l}\text { Spring, Pleasanton, } \\
\text { CA, USA }\end{array}$ \\
\hline
\end{tabular}

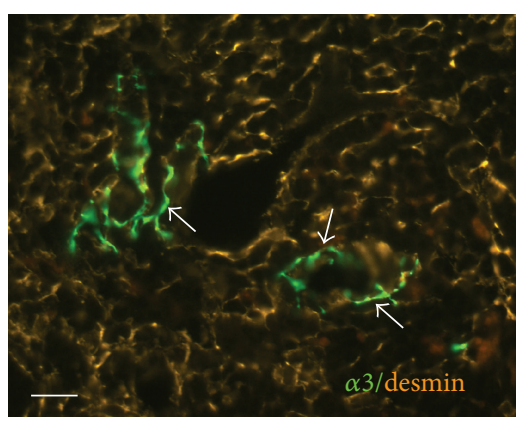

(a)

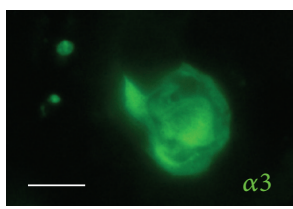

(d)

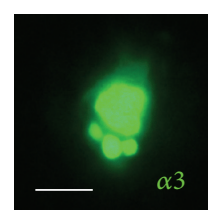

(e)

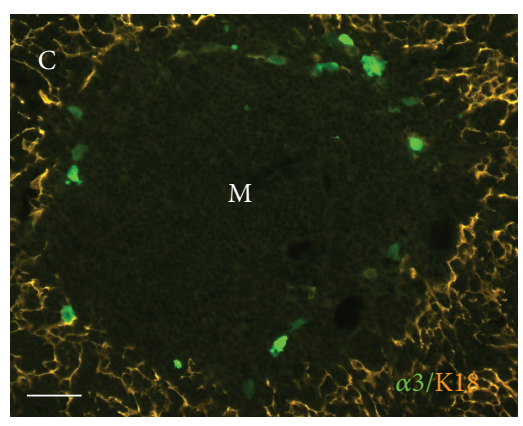

(b)

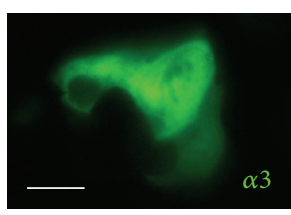

(f)

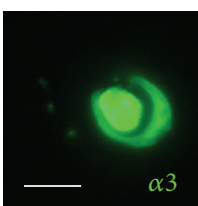

(g)

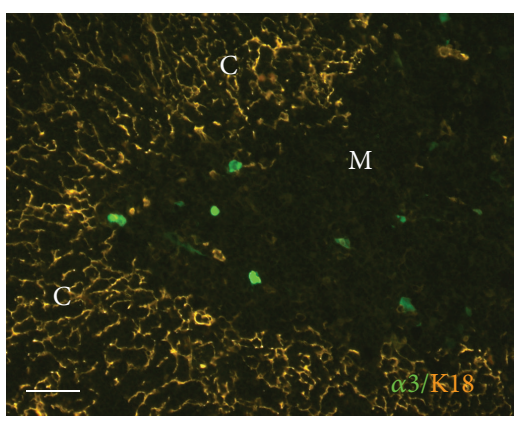

(c)

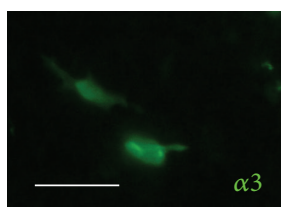

(h)

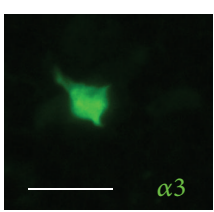

(i)

Figure 1: Chrna3-driven eGFP expression in the thymic medulla. (a) Perivascular nerve fibers (arrows) are $\alpha 3$-subunit-positive. Mesenchymal elements labeled with desmin antibody for better orientation (scale bar, $20 \mu \mathrm{m}$ ). (b), (c) $\alpha 3$-subunit-expressing cells are located in the thymic medulla and at the corticomedullary junction. Cortex delineated by immunolabeling with K18-antibodies (scale bar, $50 \mu \mathrm{m})$. (d)-(g) eGFPPositive cells either form Hassall's corpuscles-like aggregates (scale bar, $10 \mu \mathrm{m}$ ) or lie singularly (h), (i) (scale bar, $20 \mu \mathrm{m}$ ). M: medulla; C: cortex. 


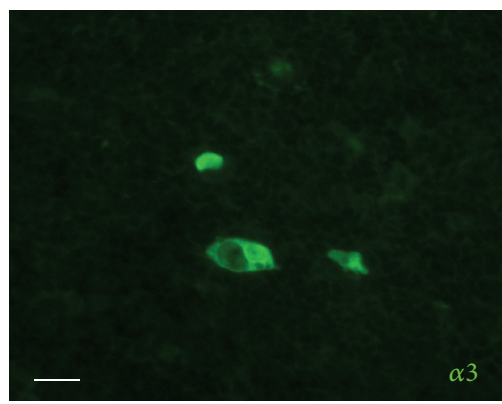

(a)

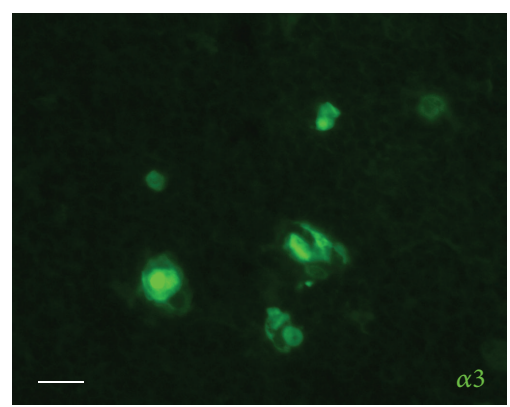

(b)

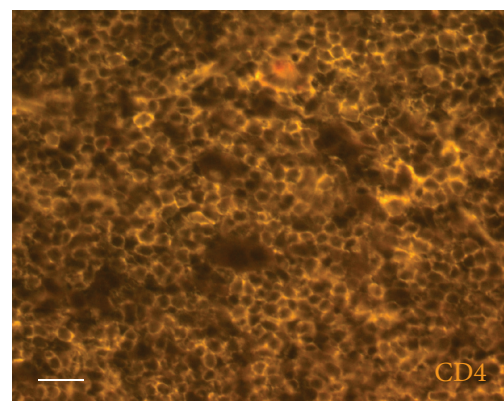

$\left(\mathrm{a}^{\prime}\right)$

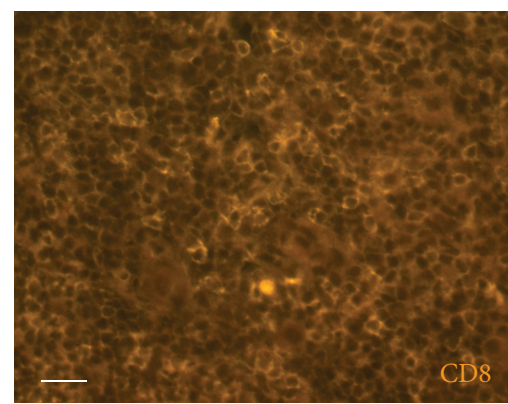

$\left(b^{\prime}\right)$

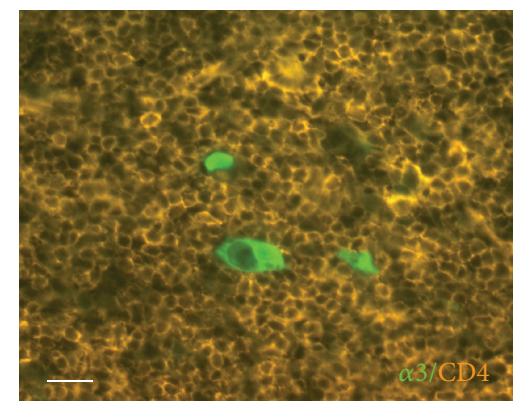

$\left(a^{\prime \prime}\right)$

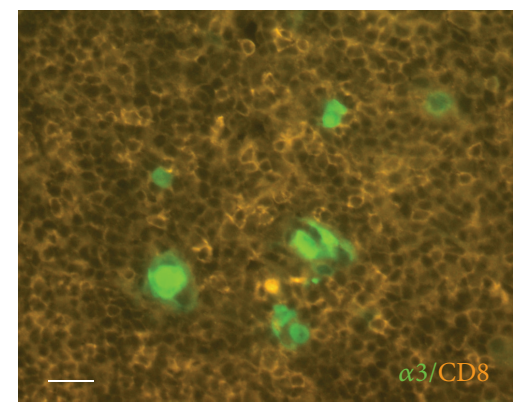

$\left(b^{\prime \prime}\right)$

FIGURE 2: eGFP-positive cells are not thymocytes. Immunostaining for CD4 (a)-(a") and CD8 (b)-( $\left.{ }^{\prime \prime}\right)$ revealed no colocalization with eGFP signal. Scale bar, $20 \mu \mathrm{m}$.

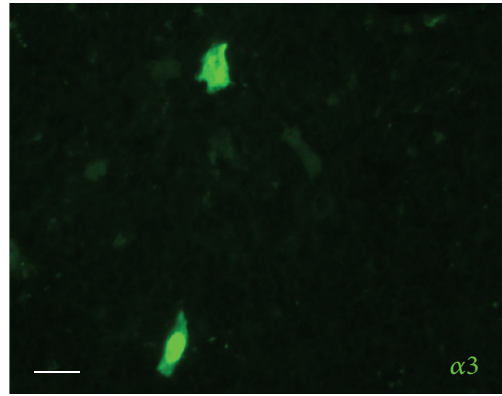

(a)

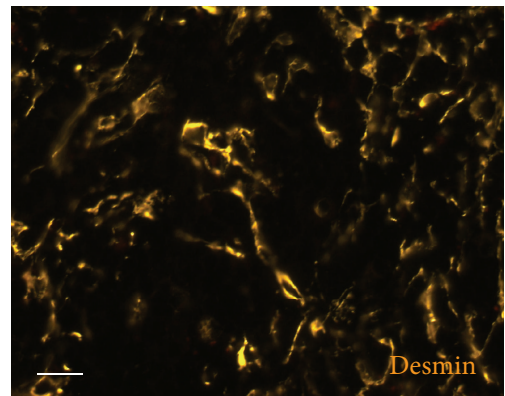

$\left(a^{\prime}\right)$

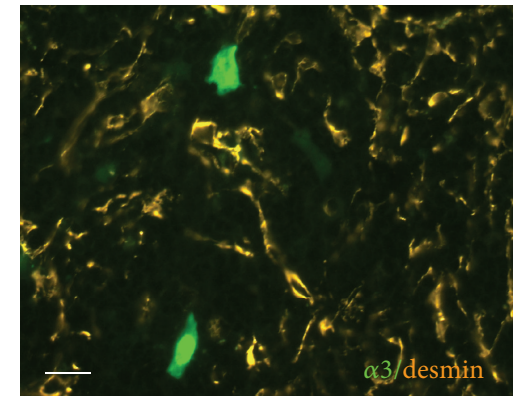

$\left(a^{\prime \prime}\right)$

Figure 3: Alpha3-subunit-expressing cells are neither myoid nor mesenchymal cells, since there is no colocalization with desminimmunoreactivity (scale bar, $20 \mu \mathrm{m}$ ).

eGFP fluorescence which is first seen in the stratum granulosum and extends into the stratum corneum (Figure 5(b)). The same pattern of extensive but not complete overlap of eGFP- and K10-immunoreactivity was found in the thymus (Figure 5(c)).

In addition, there was partial colocalization of eGFP with chromogranin A (CGA) in the thymus. CGA- immunoreactive cells were found mainly in the medulla, often attached to Hassall's corpuscle-like structures, as previously reported [37, 38] (Figure 6). CGA-immu-noreactive granules were observed in a population of eGFP-positive cells, although $\mathrm{CGA}^{+} / \mathrm{eGFP}^{-}$and $\mathrm{CGA}^{-} / \mathrm{eGFP}^{+}$cells were also present in about equal proportions (Figure 6).

\section{Discussion}

The present study demonstrates that the most abundantly expressed $\mathrm{nAChR}$ subunit in the murine thymus, the $\alpha 3$ subunit, is localized to a distinct mTEC type, that is, terminally differentiated mTEC expressing K10. In the skin, eGFP expression driven by the chrna3 promoter was more restricted than expected from previous immunohistochemical studies utilizing $\alpha 3$-subunit antibodies [39, 40], which possibly originates from the noted specificity problems of nAChR subunit antibodies documented by the use of respective gene-deficient mice [21]. In the epidermis, where keratinocytes undergo stepwise differentiation while migrating through the different layers towards the surface, we 


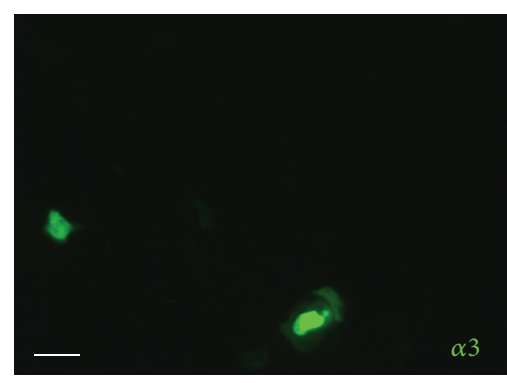

(a)

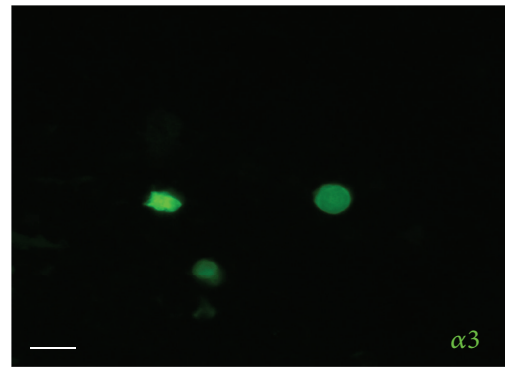

(b)

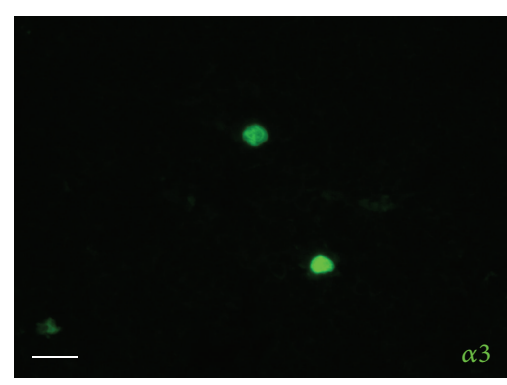

(c)

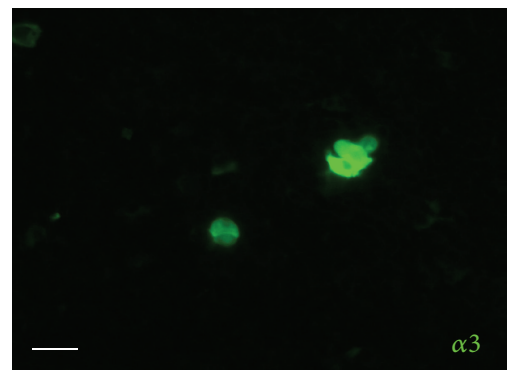

(d)

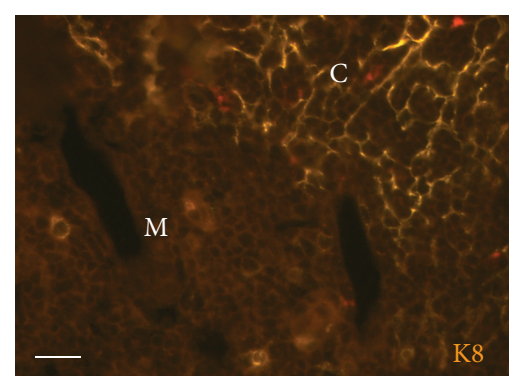

$\left(a^{\prime}\right)$

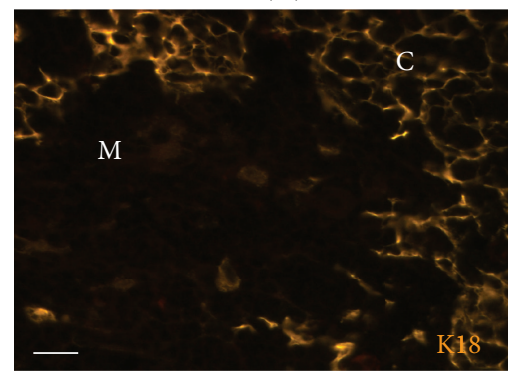

$\left(b^{\prime}\right)$

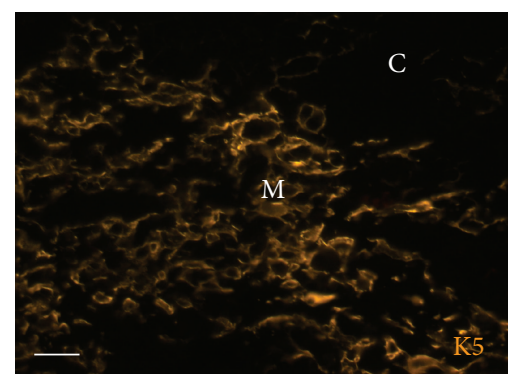

$\left(c^{\prime}\right)$

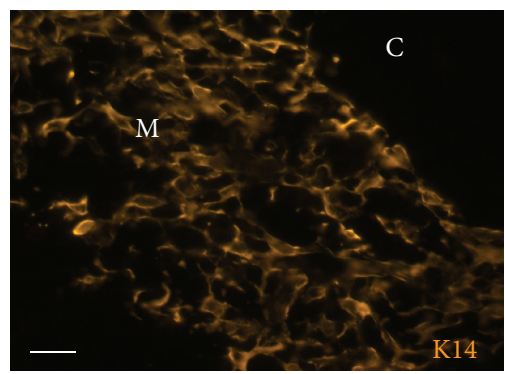

$\left(d^{\prime}\right)$

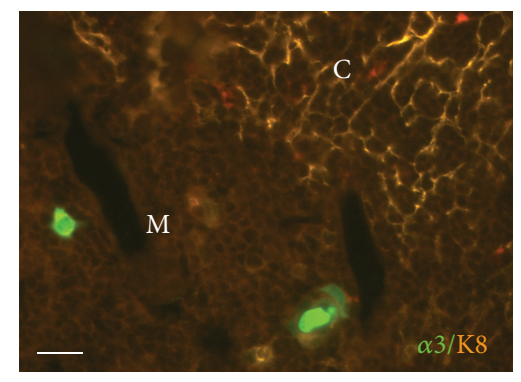

$\left(a^{\prime \prime}\right)$

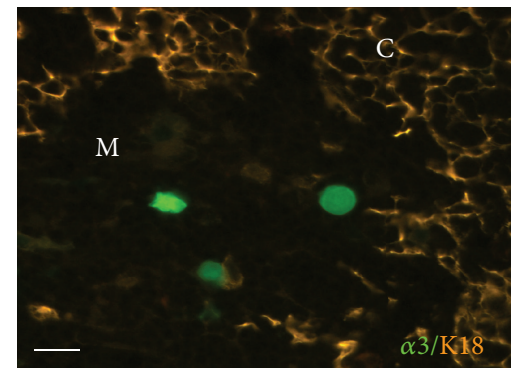

$\left(b^{\prime \prime}\right)$

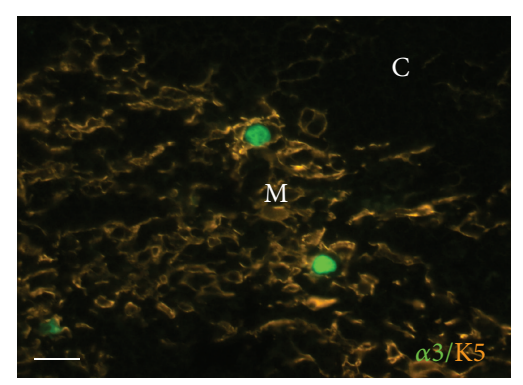

$\left(c^{\prime \prime}\right)$

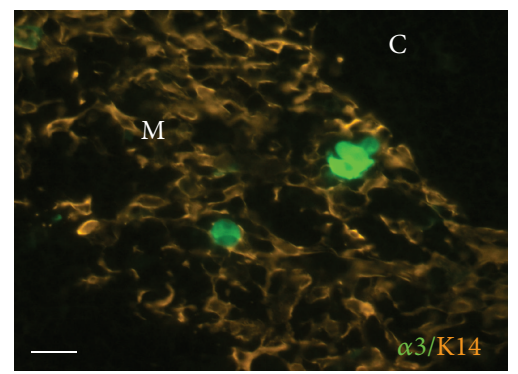

$\left(d^{\prime \prime}\right)$

FIGURE 4: Neither cortex- $(\mathrm{K} 8, \mathrm{~K} 18)$ nor medulla-specific $(\mathrm{K} 5, \mathrm{~K} 15)$ cytokeratins are expressed by $\alpha 3$-subunit-positive cells. Immunostaining

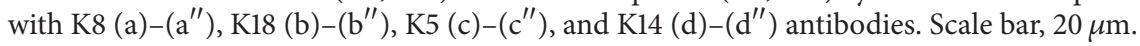

saw K10 prior to eGFP expression and eGFP shortly after keratinization when K10 was no longer detectable. This sequence of expression (K10 before $\mathrm{nAChR} \alpha 3$ ) suggests that the known promoting effect of nicotine on K10 expression by keratinocytes [41] is not driven by $\alpha 3$-subunit containing nAChR but likely by another nAChR subtype, for example, $\alpha 7$ or $\alpha 9 \alpha 10 \mathrm{nAChR}$, also known to be expressed in keratinocytes $[39,41-43]$.

Assuming the same sequence of differentiation in Hassall's corpuscle-like structures, the few $\mathrm{K}^{+} 0^{+} / \mathrm{eGFP}^{-}$and $\mathrm{K} 10^{-} / \mathrm{eGFP}^{+}$cells in the thymic medulla would not represent an entirely distinct cell population but mTEC at corresponding intermediate stages of differentiation. When K10 is ectopically expressed in K5-positive mTEC, the thymus presents premature involution with increased apoptosis and reduced proliferation of thymocytes [44] but this does not necessarily allow conclusions about physiologically K10expressing terminal mTEC.

Terminally differentiated mTEC, also characterized by expression of involucrin, no longer express the autoimmune regulator (Aire) which plays a pivotal role in establishing selftolerance by negative selection and $\mathrm{FoxP}^{+}$regulatory $\mathrm{T}$ cell 


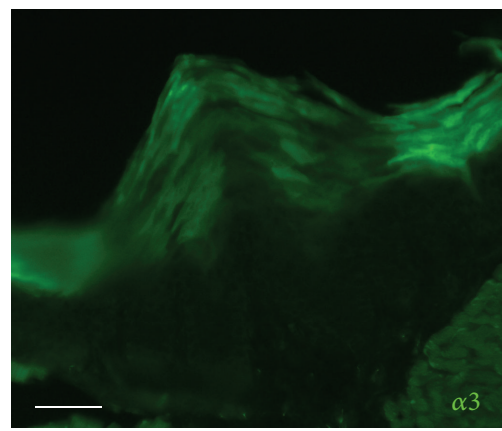

(a)

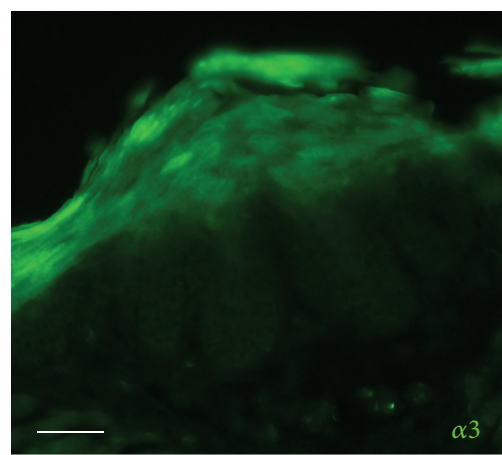

(b)

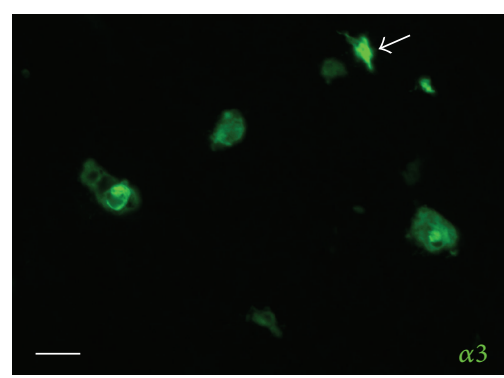

(c)

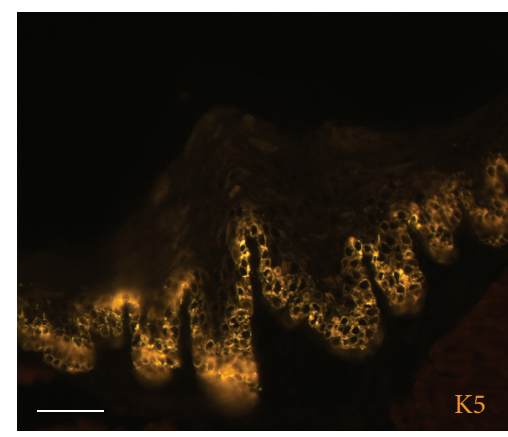

$\left(\mathrm{a}^{\prime}\right)$

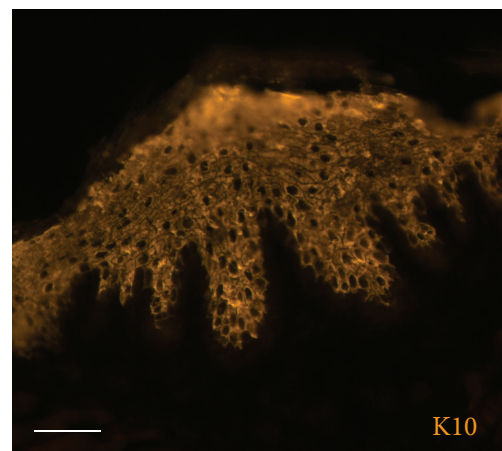

$\left(b^{\prime}\right)$

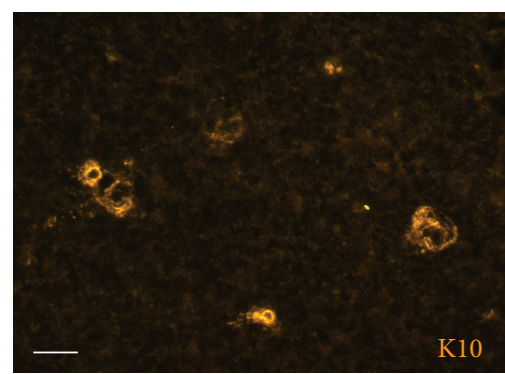

$\left(c^{\prime}\right)$

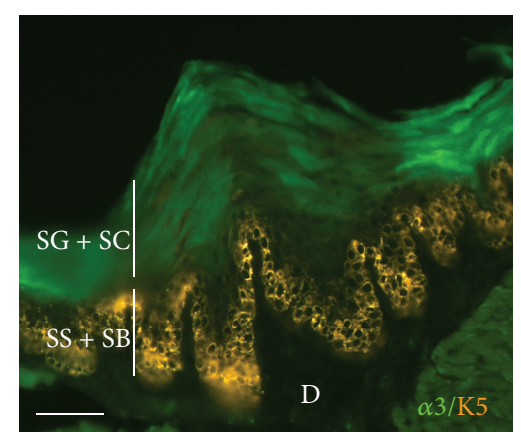

$\left(a^{\prime \prime}\right)$

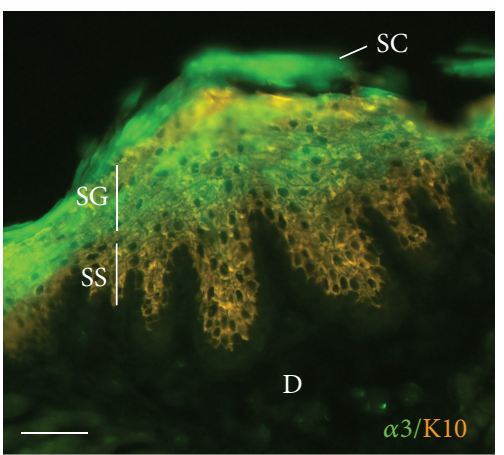

$\left(b^{\prime \prime}\right)$

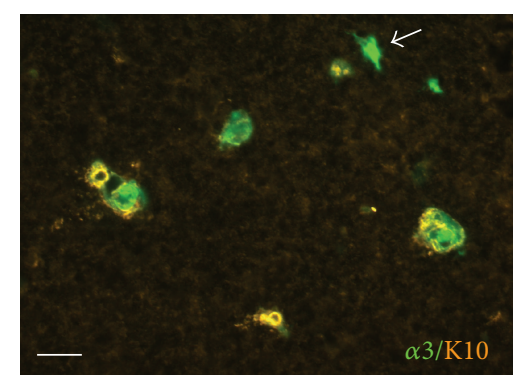

$\left(c^{\prime \prime}\right)$

FIGURE 5: Alpha3-subunit-positive cells are terminally differentiated epithelial cells. (a)-(a") Chrna3-driven eGFP fluorescence in the stratum granulosum (SG) and stratum corneum (SC) of the epidermis, K5-immunoreactivity in the lowermost stratum spinosum (SS) and stratum basale (SB). D: dermis. Scale bar, $50 \mu \mathrm{m}$. (b)-( $\left.\mathrm{b}^{\prime \prime}\right)$ K10-immunoreactivity in stratum granulosum and stratum spinosum, overlapping with eGFP signal in stratum granulosum. Scale bar, $50 \mu \mathrm{m}$. (c)-( $\left.\mathrm{c}^{\prime \prime}\right)$ The majority of $\alpha 3$-subunit-expressing cells in the thymus are K10immunoreactive; arrow points to an infrequently occurring K10-negative cell. Scale bar, $20 \mu \mathrm{m}$.

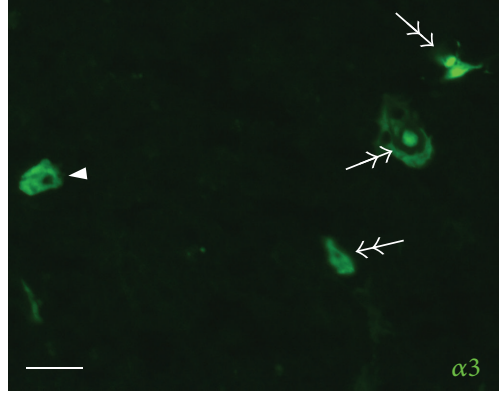

(a)

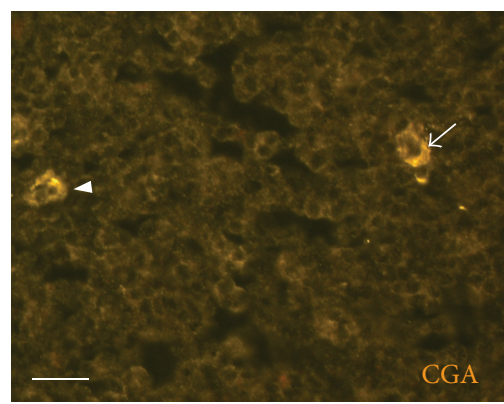

$\left(a^{\prime}\right)$

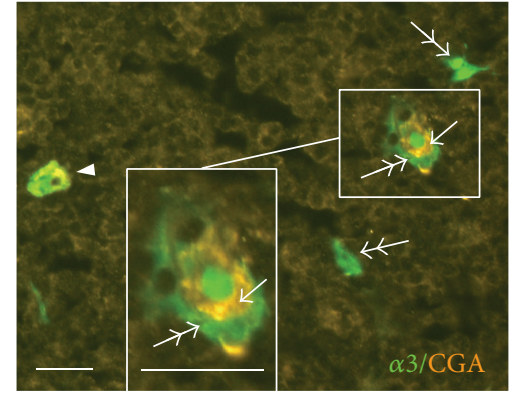

$\left(a^{\prime \prime}\right)$

FIGURE 6: Immunolabeling for CGA. Both double- $\left(\mathrm{eGFP}^{+} / \mathrm{CGA}^{+}\right.$, arrowhead) and single-labeled cells (eGFP ${ }^{+} / \mathrm{CGA}^{-}$, double-headed arrow; $\mathrm{eGFP}^{-} / \mathrm{CGA}^{+}$, arrow) can be observed. CGA-immunoreactive and eGFP-positive cells occur together in Hassall's corpuscle-like structures (higher magnification in inset). Scale bar, $20 \mu \mathrm{m}$. 
(Treg) production [31]. Human Hassall's corpuscles express thymic stromal lymphopoietin which activates medullary dendritic cells to express high levels of CD28 ligands (CD80 and CD86) [45]. Such activated dendritic cells induce the generation of $\mathrm{CD} 4^{+} \mathrm{CD} 8^{-} \mathrm{CD} 25^{+} \mathrm{T}$ cells, leading to the suggestion that Hassall's corpuscles, via dendritic cells, trigger secondary positive selection of medium-to-high affinity selfreactive $\mathrm{T}$ cells resulting in Treg generation in the thymic medulla [45]. In mice, however, Treg develop normally in lymphotoxin $\beta$-receptor-deficient mice which lack terminally differentiated mTEC as judged from the absence of involucrin ${ }^{+}$cells in the medulla $[31,46]$. Thus, the function of terminally differentiated mTEC clusters is still unclear.

CGA, originally isolated from chromaffin cells of the adrenal medulla and later found to be produced by other endocrine cell types, is also expressed in epidermal keratinocytes in the stratum granulosum [47] which is again in parallel to CGA-immunoreactivity in Hassall's corpuscles [37, 38]. Its peptide fragment catestatin has multiple biological activities, including suppression of proinflammatory cytokine release by and increasing p-STAT3 levels in peritoneal and bone marrow-derived macrophages [48]. The present findings suggest that its thymic production and/or release are under cholinergic control involving $\mathrm{nAChR}$ containing the $\alpha 3$-subunit. On the other hand, catestatin is an inhibitor of $\alpha 3 \beta 4 \mathrm{nAChR}$ [49], so that it might act in an autoinhibitory feedback in $\alpha 3$-subunit-expressing terminally differentiated mTEC.

Except terminally differentiated mTEC and autonomic nerve endings, no further cellular elements of the thymus expressed chrna3-driven eGFP in the present study. In contrast, RT-PCR revealed mRNA coding for $\alpha 3$ - and $\beta 4$ subunits in isolated human $\mathrm{CD} 4^{+} \mathrm{CD} 8^{+}$thymocytes [18]. This discrepancy might be due to species differences or incomplete expression of the transgene in the mouse strain used in this study.

In conclusion, the present study identifies nAChR $\alpha 3$ subunit expression by terminally differentiated mTEC. Their function is still unclear, which has been ascribed at least partly to the lack of adequate models allowing for isolating these cells [31], a problem that might be overcome utilizing the $\mathrm{nAChR} \alpha 3^{\mathrm{BAC}}-\mathrm{eGFP}$ mouse strain analyzed in this study.

\section{Conflict of Interests}

The authors declare that there is no conflict of interests regarding the publication of this paper.

\section{Acknowledgments}

The authors thank Dr. Ines Ibanez-Tallon, MDC Berlin, Germany, for providing the Chrna $3^{\mathrm{BAC}}$-eGFP mouse strain, and M. Bodenbenner, A. Goldenberg, T. Papadakis, and L. Renno for skillful technical assistance. This study was supported by HMWK, LOEWE Research Focus Non-neuronal cholinergic systems.

\section{References}

[1] A. J. Middlebrook, C. Martina, Y. Chang, R. J. Lukas, and D. DeLuca, "Effects of nicotine exposure on T cell development in fetal thymus organ culture: arrest of T cell maturation," The Journal of Immunology, vol. 169, no. 6, pp. 2915-2924, 2002.

[2] A. Antonica, F. Magni, L. Mearini, and N. Paolocci, "Vagal control of lymphocyte release from rat thymus," Journal of the Autonomic Nervous System, vol. 48, no. 3, pp. 187-197, 1994.

[3] W. Maslinski, E. Grabczewska, H. Laskowska-Bozek, and J. Ryzewski, "Expression of muscarinic cholinergic receptors during T cell maturation in the thymus," European Journal of Immunology, vol. 17, no. 7, pp. 1059-1063, 1987.

[4] J. C. Nordman, P. Muldoon, S. Clark, M. I. Damaj, and N. Kabbani, "The alpha- 4 nicotinic receptor promotes $\mathrm{CD}^{+}{ }^{+} \mathrm{T}$-cell proliferation and a helper T-cell immune response," Molecular Pharmacology, vol. 85, no. 1, pp. 50-61, 2014.

[5] I. Rinner, A. Globerson, K. Kawashima, W. Korsatko, and K. Schauenstein, "A possible role for acetylcholine in the dialogue between thymocytes and thymic stroma," NeuroImmunoModulation, vol. 6, no. 1-2, pp. 51-55, 1999.

[6] M. A. Tria, G. Vantini, M. G. Fiori, and A. Rossi, "Choline acetyltransferase activity in murine thymus," Journal of Neuroscience Research, vol. 31, no. 2, pp. 380-386, 1992.

[7] K. Kawashima and T. Fujii, "Expression of non-neuronal acetylcholine in lymphocytes and its contribution to the regulation of immune function," Frontiers in Bioscience, vol. 9, pp. 2063-2085, 2004.

[8] M. Schluep, N. Willcox, A. Vincent, G. K. Dhoot, and J. Newsom-Davis, "Acetylcholine receptors in human thymic myoid cells in situ: an immunohistological study," Annals of Neurology, vol. 22, no. 2, pp. 212-222, 1987.

[9] A. Wakkach, S. Poea, E. Chastre et al., "Establishment of a human thymic myoid cell line: phenotypic and functional characteristics," The American Journal of Pathology, vol. 155, no. 4, pp. 1229-1240, 1999.

[10] E. K. Engel, J. L. Trotter, D. E. McFarlin, and C. L. McIntosh, "Thymic epithelial cell contains acetylcholine receptor," The Lancet, vol. 1, no. 8025, pp. 1310-1311, 1977.

[11] L. M. Wheatley, D. Urso, K. Tumas, J. Maltzman, E. Loh, and A. I. Levinson, "Molecular evidence for the expression of nicotinic acetylcholine receptor $\alpha$-chain in mouse thymus," The Journal of Immunology, vol. 148, no. 10, pp. 3105-3109, 1992.

[12] A. Wakkach, T. Guyon, C. Bruand, S. Tzartos, S. CohenKaminsky, and S. Berrih-Aknin, "Expression of acetylcholine receptor genes in human thymic epithelial cells: implications for myasthenia gravis," The Journal of Immunology, vol. 157, no. 8, pp. 3752-3760, 1996.

[13] R. Bruno, L. Sabater, E. Tolosa et al., "Different patterns of nicotinic acetylcholine receptor subunit transcription in human thymus," Journal of Neuroimmunology, vol. 149, no. 1-2, pp. 147159, 2004.

[14] S. Poëa-Guyon, P. Christadoss, R. le Panse et al., "Effects of cytokines on acetylcholine receptor expression: implications for myasthenia gravis," The Journal of Immunology, vol. 174, no. 10, pp. 5941-5949, 2005.

[15] R. J. Lukas, J. P. Changeux, N. Le Novère et al., "International union of pharmacology. XX. Current status of the nomenclature for nicotinic acetylcholine receptors and their subunits," Pharmacological Reviews, vol. 51, no. 2, pp. 397-401, 1999.

[16] A. B. Elgoyhen, D. E. Vetter, E. Katz, C. V. Rothlin, S. F. Heinemann, and J. Boulter, "Alpha10: a determinant of nicotinic 
cholinergic receptor function in mammalian vestibular and cochlear mechanosensory hair cells," Proceedings of the National Academy of Sciences of the United States of America, vol. 98, no. 6, pp. 3501-3506, 2001.

[17] L. R. Lustig, H. Peng, H. Hiel, T. Yamamoto, and P. A. Fuchs, "Molecular cloning and mapping of the human nicotinic acetylcholine receptor $\alpha 10$ (CHRNA10)," Genomics, vol. 73, no. 3, pp. 272-283, 2001.

[18] M. Mihovilovic, S. Denning, Y. Mai, L. P. Whichard, D. D. Patel, and A. D. Roses, "Thymocytes and cultured thymic epithelial cells express transcripts encoding $\alpha-3, \alpha-5$ and $\beta-4$ subunits of neuronal nicotinic acetylcholine receptors: preferential transcription of the $\alpha-3$ and $\beta-4$ genes by immature CD $4+8+$ thymocytes," Journal of Neuroimmunology, vol. 79, no. 2, pp. 176-184, 1997.

[19] Y. Kuo, L. Lucero, J. Michaels, D. DeLuca, and R. J. Lukas, "Differential expression of nicotinic acetylcholine receptor subunits in fetal and neonatal mouse thymus," Journal of Neuroimmunology, vol. 130, no. 1-2, pp. 140-154, 2002.

[20] F. Mazzo, F. Pistillo, G. Grazioso et al., "Nicotine-modulated subunit stoichiometry affects stability and trafficking of $\alpha 3 / \beta 4$ nicotinic receptor," The Journal of Neuroscience, vol. 33, no. 30, pp. 12316-12328, 2013.

[21] N. Moser, N. Mechawar, I. Jones et al., "Evaluating the suitability of nicotinic acetylcholine receptor antibodies for standard immunodetection procedures," Journal of Neurochemistry, vol. 102, no. 2, pp. 479-492, 2007.

[22] S. Frahm, M. A. Ślimak, L. Ferrarese et al., "Aversion to nicotine is regulated by the balanced activity of $\beta 4$ and $\alpha 5$ nicotinic receptor subunits in the medial habenula," Neuron, vol. 70, no. 3, pp. 522-535, 2011.

[23] D. B. Klug, C. Carter, E. Crouch, D. Roop, C. J. Conti, and E. R. Richie, "Interdependence of cortical thymic epithelial cell differentiation and T-lineage commitment," Proceedings of the National Academy of Sciences of the United States of America, vol. 95, no. 20, pp. 11822-11827, 1998.

[24] N. M. Danzl, S. Jeong, Y. Choi, and K. Alexandropoulos, "Identification of novel thymic epithelial cell subsets whose differentiation is regulated by RANKL and Traf6," PLoS ONE, vol. 9, no. 1, Article ID e86129, 2014.

[25] E. J. de Waal and L. H. Rademakers, "Heterogeneity of epithelial cells in the rat thymus," Microscopy Research and Technique, vol. 38, no. 3, pp. 227-236, 1997.

[26] H. J. Schuurman, C. F. Kuper, and M. D. Kendall, "Thymic microenvironment at the light microscopic level," Microscopy Research and Technique, vol. 38, no. 3, pp. 216-226, 1997.

[27] B. von Gaudecker, M. D. Kendall, and M. A. Ritter, "Immunoelectron microscopy of the thymic epithelial microenvironment," Microscopy Research and Technique, vol. 38, no. 3, pp. 237-249, 1997.

[28] E. N. Lee, J. K. Park, J. R. Lee et al., "Characterization of the expression of cytokeratins 5, 8, and 14 in mouse thymic epithelial cells during thymus regeneration following acute thymic involution," Anatomy \& Cell Biology, vol. 44, no. 1, pp. 14-24, 2011.

[29] W. Savino and M. Dardenne, "Immunohistochemical studies on a human thymic epithelial cell subset defined by the anticytokeratin 18 monoclonal antibody," Cell and Tissue Research, vol. 254, no. 1, pp. 225-231, 1988.
[30] D. B. Klug, C. Carter, I. B. Gimenez-Conti, and E. R. Richie, "Cutting edge: thymocyte-independent and thymocytedependent phases of epithelial patterning in the fetal thymus," The Journal of Immunology, vol. 169, no. 6, pp. 2842-2845, 2002.

[31] A. J. White, K. Nakamura, W. E. Jenkinson et al., "Lymphotoxin signals from positively selected thymocytes regulate the terminal differentiation of medullary thymic epithelial cells," The Journal of Immunology, vol. 185, no. 8, pp. 4769-4776, 2010.

[32] W. G. Forssmann, S. Ito, E. Weihe, A. Aoki, M. Dym, and D. W. Fawcett, "An improved perfusion fixation method for the testis," Anatomical Record, vol. 188, no. 3, pp. 307-314, 1977.

[33] S. Rassadi, A. Krishnaswamy, B. Pié, R. McConnell, M. H. Jacob, and E. Cooper, "A null mutation for the $\alpha 3$ nicotinic acetylcholine (ACh) receptor gene abolishes fast synaptic activity in sympathetic ganglia and reveals that ACh output from developing preeanglionic terminals is regulated in an activitydependent retrograde manner," Journal of Neuroscience, vol. 25, no. 37, pp. 8555-8566, 2005.

[34] E. Shezen, E. Okon, H. Ben-Hur, and O. Abramsky, "Cytokeratin expression in human thymus: immunohistochemical mapping," Cell and Tissue Research, vol. 279, no. 1, pp. 221-231, 1995.

[35] R. Moll, W. W. Franke, D. L. Schiller, B. Geiger, and R. Krepler, "The catalog of human cytokeratins: patterns of expression in normal epithelia, tumors and cultured cells," Cell, vol. 31, no. 1, pp. 11-24, 1982.

[36] E. Fuchs and H. Green, "Changes in keratin gene expression during terminal differentiation of the keratinocyte," Cell, vol. 19, no. 4, pp. 1033-1042, 1980.

[37] W. J. Ginda, M. Gratzl, A. Mayerhofer, and J. B. Warchol, "Chromogranin A immunoreactivity in epithelial cells of the thymus," Folia Histochemica et Cytobiologica, vol. 34, no. 2, pp. 91-93, 1996.

[38] M. Raica, S. Encică, A. Motoc, A. M. Cîmpean, T. Scridon, and M. Bârsan, "Structural heterogeneity and immunohistochemical profile of Hassall corpuscles in normal human thymus," Annals of Anatomy, vol. 188, no. 4, pp. 345-352, 2006.

[39] H. Kurzen, H. Berger, C. Jäger et al., "Phenotypical and molecular profiling of the extraneuronal cholinergic system of the skin," Journal of Investigative Dermatology, vol. 123, no. 5, pp. 937-949, 2004.

[40] F. Kindt, S. Wiegand, V. Niemeier et al., "Reduced expression of nicotinic $\alpha$ subunits 3, 7, 9 and 10 in lesional and nonlesional atopic dermatitis skin but enhanced expression of $\alpha$ subunits 3 and 5 in mast cells," British Journal of Dermatology, vol. 159, no. 4, pp. 847-857, 2008.

[41] S. A. Grando, R. M. Horton, T. M. Mauro, D. A. Kist, T. X. Lee, and M. V. Dahl, "Activation of keratinocyte nicotinic cholinergic receptors stimulates calcium influx and enhances cell differentiation," Journal of Investigative Dermatology, vol. 107, no. 3, pp. 412-418, 1996.

[42] J. Arredondo, V. T. Nguyen, A. I. Chernyavsky et al., "Central role of $\alpha 7$ nicotinic receptor in differentiation of the stratified squamous epithelium," Journal of Cell Biology, vol. 159, no. 2, pp. 325-336, 2002.

[43] A. I. Chernyavsky, J. Arredondo, D. E. Vetter, and S. A. Grando, "Central role of $\alpha 9$ acetylcholine receptor in coordinating keratinocyte adhesion and motility at the initiation of epithelialization," Experimental Cell Research, vol. 313, no. 16, pp. 35423555, 2007.

[44] M. Santos, P. Río, S. Ruiz et al., "Altered T cell differentiation and notch signaling induced by the ectopic expression of keratin 
K10 in the epithelial cells of the thymus," Journal of Cellular Biochemistry, vol. 95, no. 3, pp. 543-558, 2005.

[45] N. Watanabe, Y. H. Wang, H. K. Lee, T. Ito, W. Cao, and Y. Liu, "Hassall's corpuscles instruct dendritic cells to induce CD4+CD25+ regulatory T cells in human thymus," Nature, vol. 436, no. 7054, pp. 1181-1185, 2005.

[46] V. C. Martins, T. Boehm, and C. C. Bleul, "Lt $\beta$ r signaling does not regulate aire-dependent transcripts in medullary thymic epithelial cells," The Journal of Immunology, vol. 181, no. 1, pp. 400-407, 2008.

[47] K. A. Radek, B. Lopez-Garcia, M. Hupe et al., "The neuroendocrine peptide catestatin is a cutaneous antimicrobial and induced in the skin after injury," Journal of Investigative Dermatology, vol. 128, no. 6, pp. 1525-1534, 2008.

[48] M. F. Rabbi, B. Labis, M. H. Metz-Boutigue, C. N. Bernstein, and J. E. Ghia, "Catestatin decreases macrophage function in two mouse models of experimental colitis," Biochemical Pharmacology, vol. 89, no. 3, pp. 386-398, 2014.

[49] B. S. Sahu, J. Mohan, G. Sahu et al., "Molecular interactions of the physiological anti-hypertensive peptide catestatin with the neuronal nicotinic acetylcholine receptor," Journal of Cell Science, vol. 125, no. 9, pp. 2323-2337, 2012. 


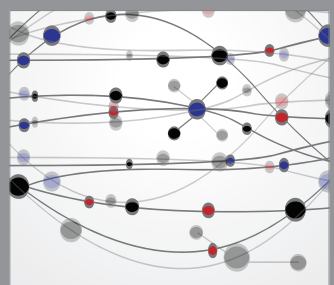

The Scientific World Journal
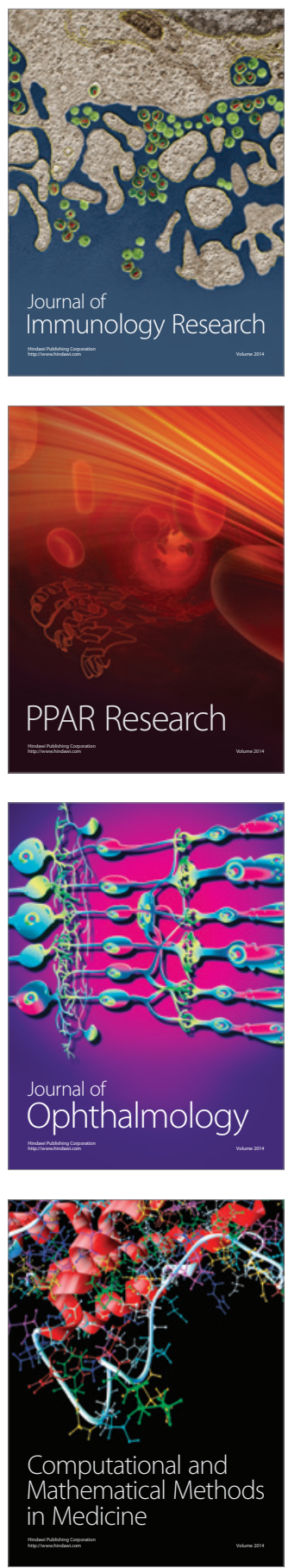

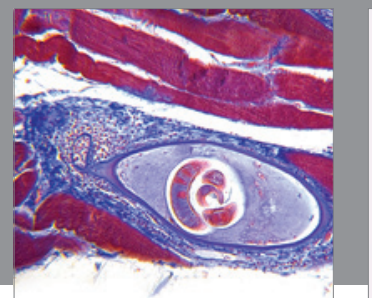

Gastroenterology

Research and Practice
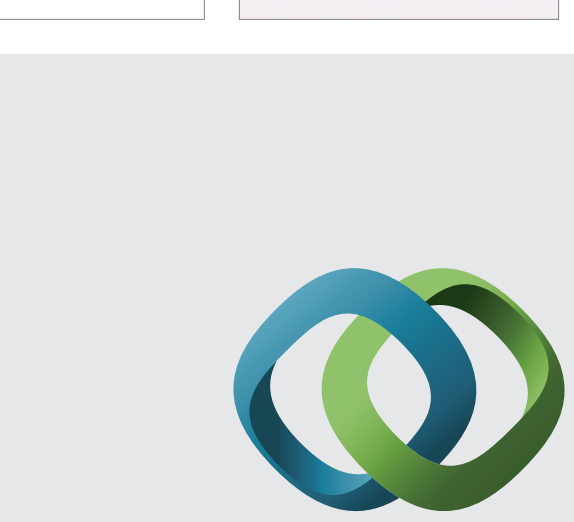

\section{Hindawi}

Submit your manuscripts at

http://www.hindawi.com
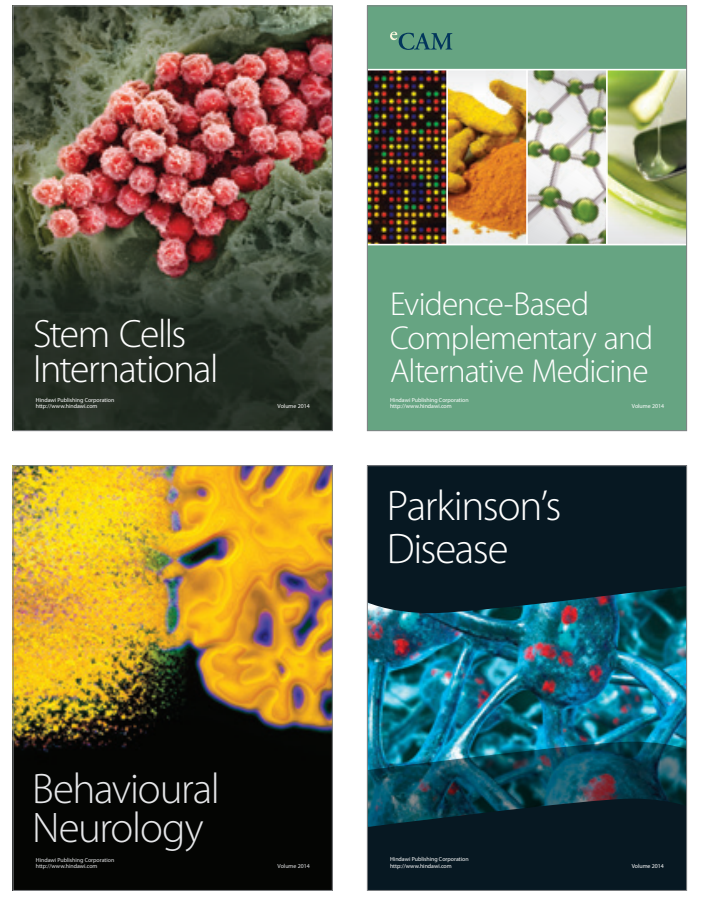
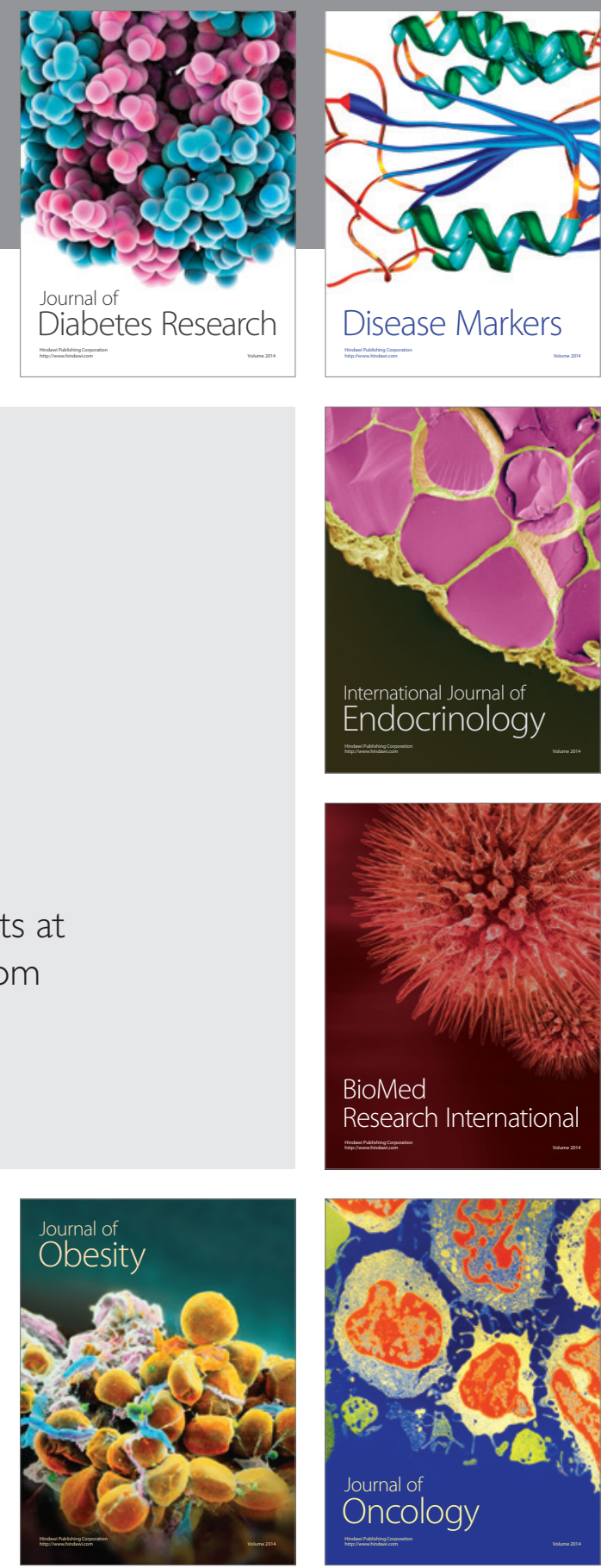

Disease Markers
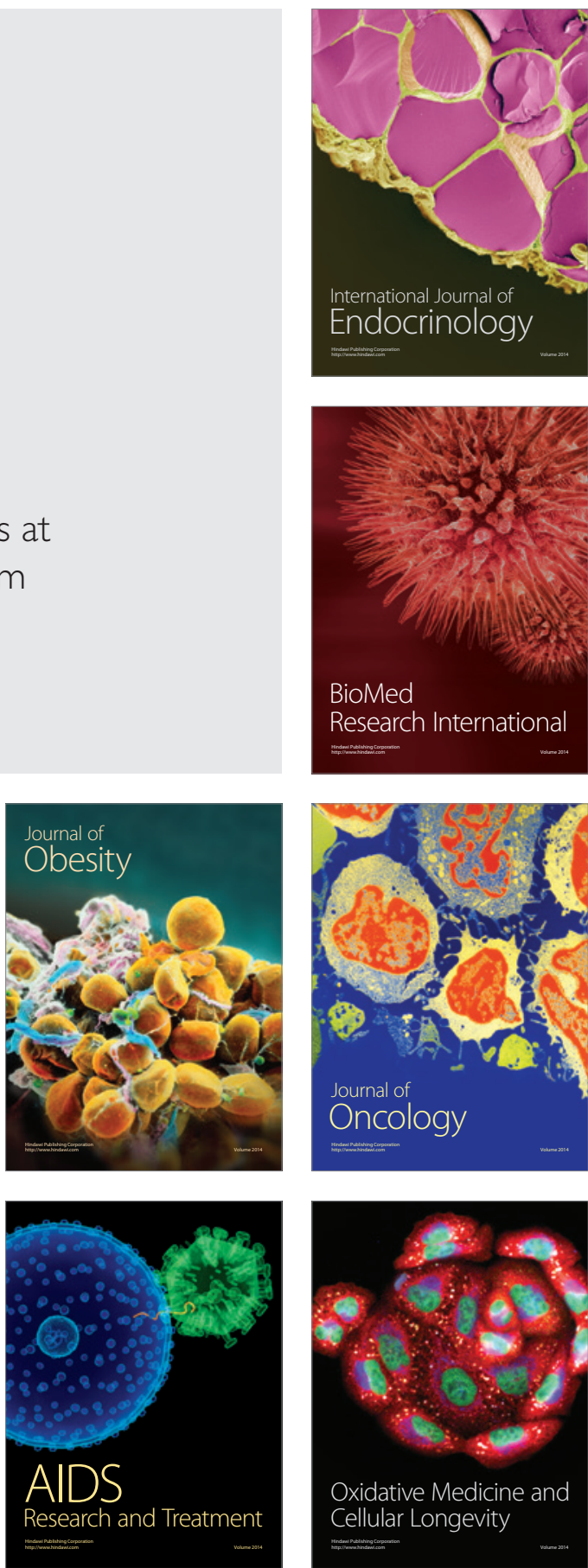